\title{
Consumer Response to Standardized Tobacco Packaging in the United Kingdom: A Synthesis of Evidence from Two Systematic Reviews
}

This article was published in the following Dove Press journal: Risk Management and Healthcare Policy

\section{Crawford Moodie* \\ Kathryn Angus (D* \\ Martine Stead*}

Institute for Social Marketing and Health, Faculty of Health Sciences and Sport, University of Stirling, Stirling, FK9 4LA, Scotland

*These authors contributed equally to this work
Correspondence: Crawford Moodie Institute for Social Marketing and Health, Faculty of Health Sciences and Sport, University of Stirling, Stirling, FK9 4LA, Scotland

Tel +44 I786467390

Email c.s.moodie@stir.ac.uk

\begin{abstract}
Standardized packaging of tobacco products has now been fully implemented in 15 countries. However, there is limited evidence, apart from in Australia, on how consumers have responded to the policy. Two systematic reviews explored consumer, tobacco industry and retailer response to standardized packaging in the United Kingdom (UK), which became mandatory for cigarettes (factory-made and hand-rolled) from May 2017, following a twelvemonth transition period. In the first review, electronic databases were searched for published primary research from January 2016 to February 2019. The second review used the same methods, with searches conducted between February 2019 and September 2020. The current study conducted a narrative synthesis of the findings exploring consumer response from these two systematic reviews. Eleven studies met the inclusion criteria. Studies examined consumer response to on-pack warnings ( $\mathrm{n}=7$ studies), appeal of packs and smoking $(\mathrm{n}=4)$, perceptions of harm $(n=5)$, and behavioral responses $(n=8)$. There was consistent evidence that standardized packaging was associated with increased warning salience and effectiveness, and reduced appeal. Findings were mixed with respect to whether standardized packs were associated with increased perceptions of harm. Standardized packaging was generally thought to deter never or occasional smokers. Standardized packaging was associated with increased thoughts of quitting during the transition period, but no study directly explored cessation or relapse prevention. Some smokers switched to cheaper cigarettes. Standardized packaging in the UK seems to be reducing the appeal of packaging and smoking and making warnings more salient, but the behavioral impact is unclear. More consumer research is needed to assess longer-term behavioral response.
\end{abstract}

Keywords: cigarettes, smoking, marketing, policy, public health, review

\section{Introduction}

Standardized packaging for tobacco products, also commonly referred to as plain packaging, was first implemented in Australia in 2012 and then in France and the UK in 2017. While initial uptake was slow, since 2018 twelve additional countries have fully implemented standardized packaging, with Belgium the fifteenth country to do so in January 2021. According to the World Health Organization's (WHO) Framework Convention on Tobacco Control, standardized packaging may reduce the appeal of tobacco products, increase the salience of the on-pack warnings, and reduce the ability of the pack to mislead consumers about the harms of smoking. ${ }^{1,2}$ As a result of these changes, standardized packaging may help discourage smoking uptake, encourage cessation and reduce relapse. . $^{3,4}$ 
Multiple reviews of standardized packaging research have been conducted. ${ }^{5-16}$ Most consider how consumers perceive standardized packaging, in terms of warning salience, appeal, harm and behavior, ${ }^{5-11,15,16}$ although some focus on particular populations, such as adolescents, ${ }^{14}$ or particular outcomes, such as cessation and initiation. ${ }^{13}$ Some reviews cover the response of not only consumers but also the tobacco industry and retailers. ${ }^{15,16}$ These reviews are important as they help policymakers, whether in countries that have implemented standardized packaging or which are considering doing so, understand the potential or actual impacts of the policy.

In the UK, as a result of the 'Standardized Packaging of Tobacco Products Regulations' ${ }^{\prime 17}$ and 'Tobacco and Related Products Regulations', ${ }^{18}$ tobacco companies have been required to sell cigarettes and rolling tobacco in standardized packs since May $20^{\text {th }}$ 2017. They were given a transition (sell-through) period of 12 months (May 2016-May 2017). The legislation stipulates that packs should be drab brown (Pantone 448C), display pictorial health warnings on at least $65 \%$ of the primary display areas (previously text warnings covered $43 \%$ of the pack front and pictorial warnings $53 \%$ of the pack reverse), and a text-only general warning (Smoking kills - quit now) and information message (Tobacco smoke contains over 70 substances known to cause cancer) on at least $50 \%$ of the secondary display areas; any standardized pack that appeared on the market during or after the transition period had to meet these requirements. Cigarette packs must contain at least 20 sticks and be sold in a "shoulder" box (a pack with the lid flush with the base and held in place by a shoulder on the base) or a cuboid-shaped flip-top pack, with beveled or rounded edges permitted. Rolling tobacco packs must contain at least 30 grams and be sold in a shoulder box, cuboid pack, cylindrical pack or pouch. A brand variant name can be displayed on packs, but the location, text color, font size, style and typeface are prescribed (see Figure 1).

Despite standardized packaging now being mandatory in 15 countries, relatively little is known about the realworld impacts on consumers in countries other than Australia; most previous reviews focus completely or mostly on research that explores the hypothetical response of consumers. Understanding how consumers react when the policy is actually implemented, as opposed to hypothetically, is important for policymakers seeking to review whether it has produced the desired impacts, as well as for countries considering introducing the policy in future.
The data from two systematic reviews, ${ }^{15,16}$ reported to Preferred Reporting Items for Systematic Reviews and Meta-Analyses (PRISMA) standards, ${ }^{19}$ are the source data analyzed in this review. The source reviews had a wider remit to also examine how the tobacco industry reacted, such as changes to products, and how the retail environment changed in response to the policy (eg, EvansReeves et $\mathrm{al}^{20}{ }^{20}$ Hiscock et $\mathrm{al}^{21}$ ). This paper focuses on how consumers (smokers and non-smokers) in the UK responded to standardized packaging, in terms of the impact of on warning salience, appeal and harm perceptions, and behavior.

\section{Methods}

In this paper, the data extracted and appraised from the consumer response studies included in the two source reviews are synthesized together.

\section{Source Reviews}

For inclusion in the two original reviews, studies had to report outcomes exploring consumer, retailer or tobacco industry responses to the implementation of standardized packaging in the UK and be published or accepted for publication in an academic journal (including conference abstracts). ${ }^{15,16}$ All primary study designs were eligible for inclusion and there was no language restriction. Studies were excluded if their data collection ended before the start of the transition period (May 20, 2016), or if they focused exclusively on legal aspects of standardized packaging. Both original reviews used the same search strategy. The databases Business Source Complete, Cochrane Library, Medline, PsycINFO, SocINDEX, Web of Science Core Collection, and World Advertising Research Center were searched for records published since the start of $2016^{15}$ and $2018^{16}$ using combinations of terms for packaging, tobacco and the UK (see Supplementary File for an example). The Bielefeld Academic Search Engine (BASE) and the 2018-20 Society for Research on Nicotine and Tobacco (SRNT) conference programs were searched with a selection of these terms. A Web of Science Citation Search was made for publications citing previous reviews of standardized packaging ${ }^{9,12-14}$ or the 11 articles included in the earlier review. ${ }^{15}$ The search strategy for both reviews was run twice, at the start and near-end of both projects (searches were run on August 15, 2018 and February 15, 2019 for the first review, ${ }^{15}$ and on May 28, 2020 and September 28, 


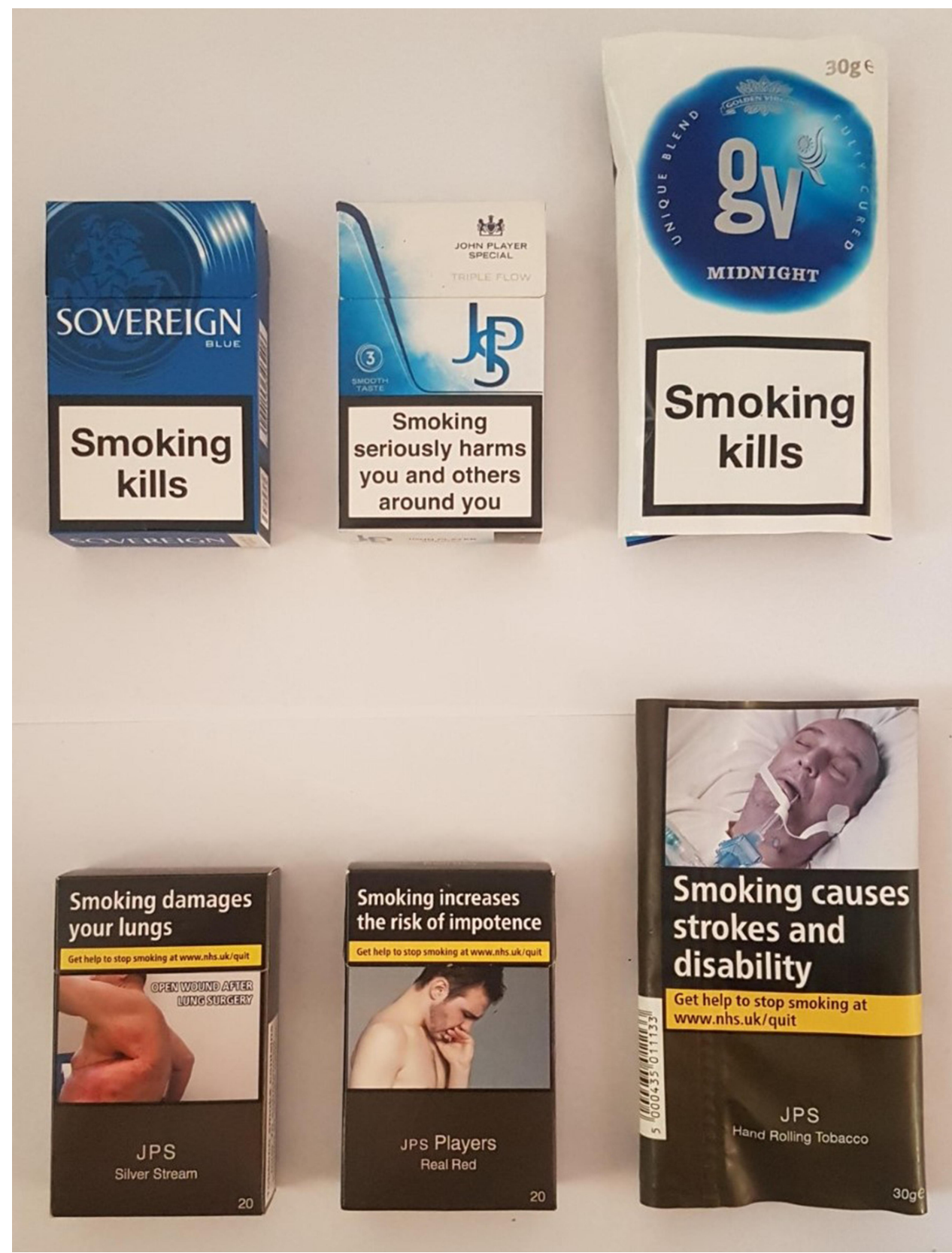

Figure I Examples of flip-top cigarette packs and rolling tobacco pouches pre-standardized packaging (top row) and post-standardized packaging (bottom row).

2020 for the $\left.\operatorname{second}^{16}\right)$. Academic topic experts were also contacted.

Study titles and abstracts were screened by one reviewer against the inclusion criteria. Potentially relevant full-text studies were obtained and screened for relevance by one reviewer. A second reviewer checked the inclusion/exclusion decisions at both stages. Data were extracted from included studies by one reviewer into a standard form for general information, study design, sample characteristics, setting, theoretical basis, outcome measures and results.
For both reviews, each study was appraised for methodological soundness by external appraisers from the Evidence for Policy and Practice Information and Co-ordinating Centre (the EPPI-Centre, University College London) to avoid potential biases resulting from the review team having co-authored some included studies. The same two external experts independently appraised all studies and met frequently to reconcile appraisals as "no", "minor" or "major" concerns for methodological soundness. Full details of their tools and methods are reported elsewhere. ${ }^{15}$ 


\section{Current Review}

For this paper, only consumer response studies from the source reviews were eligible for inclusion. The overall level of concern on methodological soundness rating was not an inclusion criterion; all studies were included and the ratings are reported in the results. However, outcome measures for awareness of, and attitudes to, standardized packs or the legislation, were excluded from this review post hoc. While awareness helps to understand when standardized packs appeared on the market, and attitudes how it is perceived, they provide no insight into the impacts of standardized packaging. Figure 2 shows the combined flow of information through the phases of the systematic reviews. The extracted data and appraisals for the eleven studies that met the inclusion criteria were examined as a whole dataset. No study appeared to contradict another. Neither a quantitative meta-analysis nor qualitative metaethnography was feasible given the heterogeneity of study designs and diversity of outcome measures. ${ }^{15,16}$ A narrative synthesis combines the findings from both reviews, structured by related outcome measures and the directions of effect. ${ }^{9}$

\section{Results}

Based on the inclusion criteria, eleven studies provided evidence for how consumers in the UK have reacted to standardized packaging. Results are reported by the appeal of packs, perceptions of harm, response to the on-pack health warnings, and self-reported behavioral responses.

\section{Appeal}

Four studies, two quantitative ${ }^{22,23}$ and two qualitative, ${ }^{24,25}$ examined appeal. Participants were asked about different facets of appeal (eg, quality, prestige, coolness, popularity), either using no visual prompts or shown images of, or actual, standardized packs. All four studies raised minor methodological concerns. Table 1 summarizes the direction of effect and/or key findings for the results of the studies.

A longitudinal study involving seven European countries, ${ }^{22}$ with Wave 1 data collected early in the standardized packaging transition period in the UK and Wave 2 data collected 9-14 months after the end of the transition period, reported a $41 \%$ increase in the percentage of participants from England who did "not at all" like the look of their cigarette pack (Wave 1: $13.9 \%$ vs Wave 2: $54.9 \%$, $\mathrm{p}<0.001)$. There were increases in three other countries in the percentage of participants who did "not at all" like the look of their cigarette packs, but the change between waves was significantly greater in England than in each of the six countries which did not have standardized packaging at the time $(p<0.05)$. Among participants in England, there was a decrease in reporting that brands differed in prestige $(p<0.01)$ between waves but an increase in reporting that the quality of their cigarettes was high/very high $(p=0.013)$. In Mitchell's ${ }^{23}$ crosssectional survey of 12- to 17-year-old never smokers in Scotland, which examined response to standardized packs with different pack structures, participants had consistently negative ratings (ie, unattractive, uncool, cheap, unfashionable, unpopular and boring) of all packs. However, a standardized pack with a "shoulder" box design was less negatively rated on several measures than other pack structures. Sub-group analysis, controlling for demographics and family and peer smoking, found no association between appeal ratings for any of the packs and smoking susceptibility.

The two qualitative studies found that standardized packs were generally unappealing to school-age young people. In MacGregor et al's ${ }^{24}$ focus groups with 13- to 16-year-old school pupils, standardized packs were described as "really ugly". The removal of key elements of branding was perceived to have reduced brand distinctiveness, reduced pack appeal and reduced the ability of a brand to promote or project a positive image or "smoker identity". Similarly, in the Mitchell et $\mathrm{al}^{25}$ focus groups with 16- to 17-year-old school pupils, packs were viewed as disgusting and off-putting, evoking feelings of embarrassment or discomfort. However, standardized packs with different structures from the regular straight-edged packs were less unappealing: shoulder packs were considered weird, cool, different and more expensive; slim packs were regarded as nicer and potentially making them feel better about smoking; and a rounded edge Marlboro pack was described by some as a "fashion statement". Different pack structures appeared to provide ways to create appeal and differentiation between packs. Some brand variant names were found to be appealing, particularly among males, and several participants noted that the brand and variant name was the only thing left on the pack to create appeal.

\section{Perceptions of Harm}

Five studies, comprising three quantitative studies ${ }^{22,23,26}$ and two qualitative studies, ${ }^{24,25}$ examined whether 


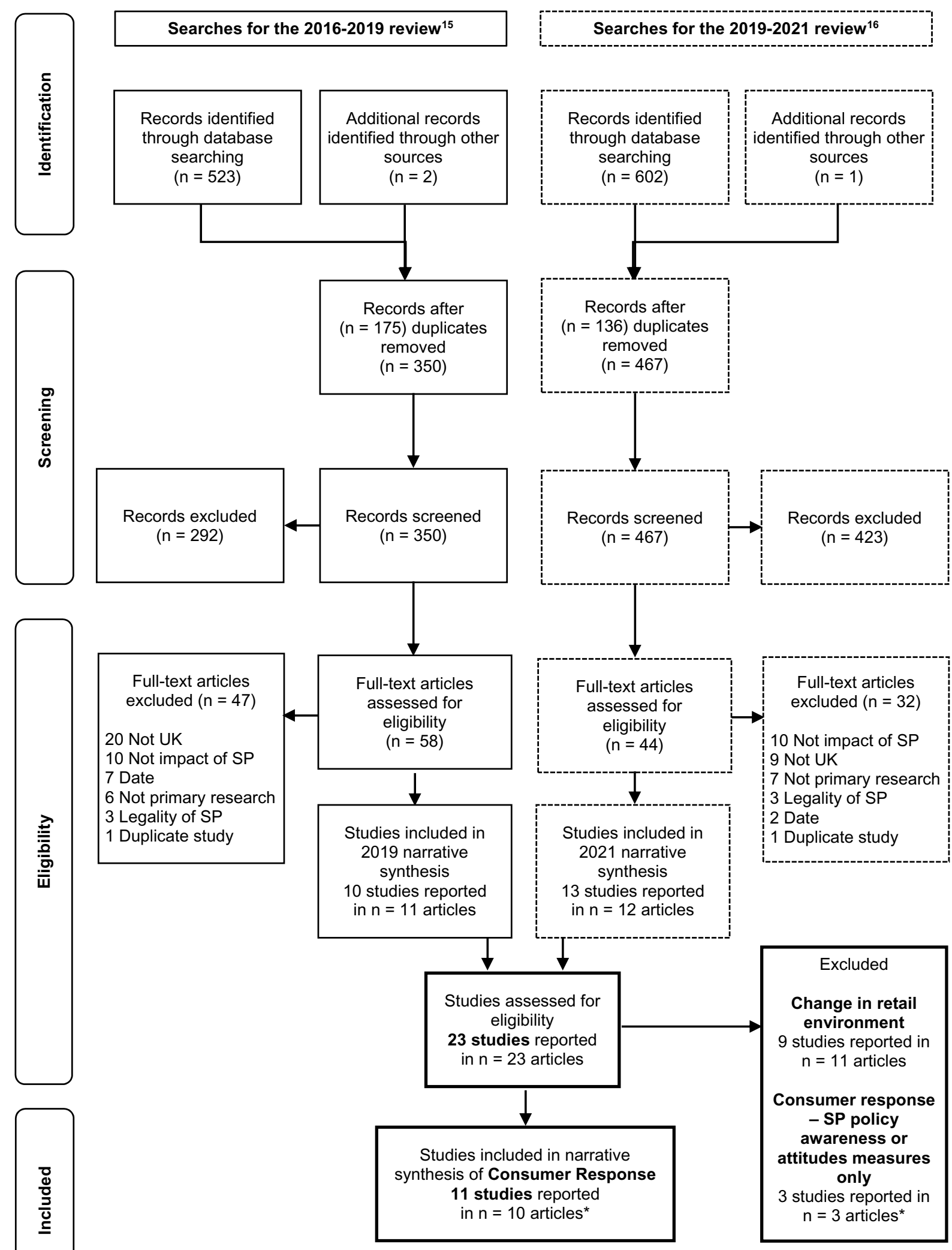

Notes: SP, standardised packaging; *One article covered 1 included and 1 excluded study.

Figure 2 Flow of information through the phases of the source and current reviews. 
Table I Direction of Effect and/or Key Findings: Appeal and Perceptions of Harm

\begin{tabular}{|c|c|c|c|c|}
\hline Study & $\begin{array}{l}\text { Study Design and Data } \\
\text { Collection }\end{array}$ & Population & $\begin{array}{l}\text { Type of Comparison/Issues } \\
\text { Explored }\end{array}$ & $\begin{array}{l}\text { Direction of Effect (Measures } \\
\text { Used) and/or Key Findings }\end{array}$ \\
\hline $\begin{array}{l}\text { Aleyan } \\
\text { et } \mathrm{al}^{22}\end{array}$ & $\begin{array}{l}\text { Longitudinal online survey } \\
\text { Wave I: Jul-Sep } 2016 \text { (early } \\
\text { in transition period) } \\
\text { Wave 2: Feb-Jul } 2018 \text { (nine- } \\
\text { I4 months after end of } \\
\text { transition period) }\end{array}$ & $\begin{array}{l}\text { Adult smokers } 18+ \\
\text { years } \\
\text { England, Germany, } \\
\text { Greece, Hungary, } \\
\text { Poland, Romania, } \\
\text { Spain } \\
\text { Wave I: } n=9547 \\
\text { Wave 2: } n=9724\end{array}$ & $\begin{array}{l}\text { Smokers in England (Tobacco } \\
\text { Products Directive new warnings } \\
\text { and UK standardized packs) vs } \\
\text { smokers in six other European } \\
\text { countries (Tobacco Products } \\
\text { Directive new warnings only) } \\
\text { Perceptions of pack and brand } \\
\text { appeal; perceptions of relative } \\
\text { harm }\end{array}$ & $\begin{array}{l}\text { Appeal: } \\
\text { Significantly greater increase in } \\
\text { participants in England who did not } \\
\text { like the look of their pack post- } \\
\text { standardized packaging in the UK. } \\
\text { Perceptions of harm: } \\
\text { No significant change in harm } \\
\text { perceptions among participants in } \\
\text { England post-standardized } \\
\text { packaging in the UK. }\end{array}$ \\
\hline $\begin{array}{l}\text { MacGregor } \\
\text { et } \mathrm{al}^{24}\end{array}$ & $\begin{array}{l}\text { Focus groups } \\
\text { Feb-Mar } 2017 \text {, towards end } \\
\text { of transition period }\end{array}$ & $\begin{array}{l}\text { Young people } 13-16 \\
\text { years } \\
\text { Mix of current } \\
\text { smokers, never } \\
\text { smokers, and tried } \\
\text { smoking } \\
\text { Scotland } \\
16 \text { groups, } n=82\end{array}$ & $\begin{array}{l}\text { Awareness of standardized packs, } \\
\text { perceptions of their appeal, and } \\
\text { potential impact on smoking } \\
\text { attitudes and behavior }\end{array}$ & $\begin{array}{l}\text { Appeal: } \\
\text { Standardized packs were seen as } \\
\text { ugly, and ability to differentiate } \\
\text { between brands was reduced. } \\
\text { Perceptions of harm: } \\
\text { Removal of 'clean', 'fresh' colors } \\
\text { perceived as reflecting harmfulness. }\end{array}$ \\
\hline $\begin{array}{l}\text { Mitchell } \\
\text { et al }{ }^{25}\end{array}$ & $\begin{array}{l}\text { Focus groups } \\
\text { Between Nov } 2017 \text { (6 } \\
\text { months after end of } \\
\text { transition period) and } \\
\text { Nov } 2018 \text { ( } 18 \text { months after } \\
\text { end of transition period) }\end{array}$ & $\begin{array}{l}\text { Young people } 16-17 \\
\text { years } \\
\text { Mix of ever and never } \\
\text { smokers } \\
\text { Scotland } \\
8 \text { groups, } n=41\end{array}$ & $\begin{array}{l}\text { Awareness and perceptions of } \\
\text { standardized packs, reactions to } \\
\text { different standardized pack } \\
\text { structures }\end{array}$ & $\begin{array}{l}\text { Appeal: } \\
\text { Standardized packs were seen as } \\
\text { off-putting and embarrassing, but } \\
\text { some pack structures were } \\
\text { regarded less negatively than } \\
\text { others. } \\
\text { Perceptions of harm: } \\
\text { Pack color thought to reflect } \\
\text { harmfulness of cigarettes. }\end{array}$ \\
\hline $\begin{array}{l}\text { Mitchell } \\
\text { et al }{ }^{23}\end{array}$ & $\begin{array}{l}\text { Cross-sectional survey in } \\
\text { schools } \\
\text { Between Nov } 2017 \text { (6 } \\
\text { months after end of } \\
\text { transition period) and } \\
\text { Nov } 2018 \text { (18 months after } \\
\text { end of transition period) }\end{array}$ & $\begin{array}{l}\text { Young people } 12-17 \\
\text { years } \\
\text { Never smokers } \\
\text { Scotland } \\
\mathrm{n}=507\end{array}$ & $\begin{array}{l}\text { Reactions to standardized cigarette } \\
\text { packaging; whether permitted } \\
\text { variations in pack structure (eg, } \\
\text { slim packs or beveled-edged packs) } \\
\text { influenced reactions. } \\
\text { Perceptions of harm to health }\end{array}$ & $\begin{array}{l}\text { Appeal: } \\
\text { Standardized packs were } \\
\text { consistently rated negatively on } \\
\text { different appeal measures, but } \\
\text { some pack structures were } \\
\text { regarded less negatively than } \\
\text { others. } \\
\text { Perceptions of harm: } \\
\text { Standardized packs consistently } \\
\text { rated as harmful, with no significant } \\
\text { differences between standardized } \\
\text { packs with different structures. }\end{array}$ \\
\hline $\begin{array}{l}\text { Moodie } \\
\text { et } \mathrm{al}^{26}\end{array}$ & $\begin{array}{l}\text { Cross-sectional online } \\
\text { survey } \\
\text { Feb-Apr 2017, towards end } \\
\text { of transition period }\end{array}$ & $\begin{array}{l}\text { Current smokers } \\
16-65+\text { years } \\
\text { England } \\
n=1865\end{array}$ & $\begin{array}{l}\text { Smokers who currently used } \\
\text { standardized packs vs smokers } \\
\text { who had never used standardized } \\
\text { packs (conducted Feb-Apr } 2017 \\
\text { when both standardized and fully } \\
\text { branded packs still on sale). } \\
\text { Whether pack made respondents } \\
\text { think about health risks of smoking }\end{array}$ & $\begin{array}{l}\text { Perceptions of harm: } \\
\text { Users of standardized packs were } \\
\text { more likely than never users of } \\
\text { standardized packs to indicate that } \\
\text { pack made them think about health } \\
\text { risks of smoking. }\end{array}$ \\
\hline
\end{tabular}


standardized packaging affected perceptions of the harm associated with smoking or cigarettes. Participants were asked about harm either using no visual prompts or shown images of, or actual, standardized packs. All five studies raised minor methodological concerns. Table 1 summarizes the direction of effect and/or key findings for the results of the studies.

The Moodie et $\mathrm{al}^{26}$ cross-sectional survey, conducted at a time when both standardized and fully branded packs were available, reported that respondents who were current users of standardized packs were more likely than never users of standardized packs to indicate that their pack made them think about the health risks of smoking (Odds Ratio $(\mathrm{OR})=2.16$, 95\% Confidence Interval $(\mathrm{CI})$ : $1.57-2.99, \mathrm{p}<0.001)$. The association remained when adjusted for demographic (age, gender, social grade) and smoking characteristics (quit attempts in past 12 months, Heaviness of Smoking Index (HSI), and currently trying to quit/reduce) (adjusted OR=1.92, 95\% CI: 1.38-2.68, $\mathrm{p}<0.001)$. Previous users of standardized packs were more likely than never users of standardized packs to say that they had thought about the health risks of smoking, although the differences were not statistically significant. Mitchell et al's ${ }^{23}$ cross-sectional survey of 12- to 17-yearold never smokers found that all of the different standardized packs shown were consistently rated as harmful, with no significant differences in ratings between standardized packs with different structures. Sub-group analysis, controlling for demographics and family and peer smoking, showed no association between harm ratings and smoking susceptibility. In a seven-country longitudinal survey, ${ }^{22}$ there was no significant change between Wave 1 (transition period) to Wave 2 (post-standardized packaging) in the percentage of participants in England who reported that their own brand was no different in harmfulness compared to other brands $(78.1 \% \mathrm{~W} 1,78.6 \% \mathrm{~W} 2)$ or that their own brand was no smoother or harsher compared to other brands $(30.4 \% \mathrm{~W} 1,32.6 \% \mathrm{~W} 2)$.

The two qualitative studies with school pupils provided some additional insights into harm perceptions. The color of standardized packs was thought, by some, to reflect the harm caused by smoking; it was also suggested that the cigarettes inside the slim standardized pack might be less harmful, due to the thinness of the pack. ${ }^{25}$ In MacGregor et al's ${ }^{24}$ focus groups, with 13- to 16-year-old school pupils, it was suggested that the removal of "clean" and "fresh" colors may indicate a change in perceived harmfulness of certain brands.

\section{Health Warnings}

Seven studies, comprising five quantitative studies ${ }^{22,26-29}$ and two qualitative studies, ${ }^{24,25}$ examined whether standardized packaging increased attention to health warnings or how people responded to the warnings. Five of the studies raised minor methodological concerns ${ }^{22,24-26,29}$ and two major methodological concerns. ${ }^{27,28}$ Table 2 summarizes the direction of effect and/or key findings for the results of the studies.

The quantitative studies raising only minor methodological concerns consistently found that standardized packaging was associated with increased warning salience. A seven-country longitudinal study, ${ }^{22}$ with data collected early in the UK standardized packaging transition period and 9-14 months after the end of the transition period, reported a $27.6 \%$ increase in the percentage of participants from England who said that the health warning was the first thing they noticed on looking at a cigarette pack $(18.3 \% \mathrm{v} 45.9 \%, \mathrm{p}<0.001)$. While the percentage of participants who noticed the warning first also increased in two other countries, the change between waves in England was significantly greater $(p<0.05)$. In a within-subjects experimental study which used eye-tracking to measure participants' eye movements when shown different packs, ${ }^{29}$ participants attended more to warnings on standardized packs than to those on fully branded packs. Bonferroniadjusted post hoc pairwise comparisons showed there were more eye fixations for the warnings on standardized packs $(\mathrm{M}=12.77$, Standard Deviation $(\mathrm{SD})=4.72)$ than on fully branded packs $(\mathrm{M}=5.49, \mathrm{SD}=3.44 ; \mathrm{p}<0.001)$. In addition, Bonferroni-adjusted post hoc pairwise comparisons showed more "first fixations" to warning areas on standardized packs (mean number of first fixations for standardized packs $(\mathrm{M}=6.48, \mathrm{SD}=2.03)$, mean number of first fixations for fully branded packs $(\mathrm{M}=1.35, \mathrm{SD}=1.61))$, with these fixations to warnings on standardized packs being for a longer duration (mean dwell-time for standardized packs ( $M=262.03, S D=158.51)$, mean dwell-time for fully branded packs $(\mathrm{M}=35.62, \mathrm{SD}=51.21)$; $\mathrm{p}$-values not reported).

In Moodie et al's ${ }^{26}$ cross-sectional survey with smokers, conducted in the late transition period when standardized and fully branded packs were concurrently on sale, current users of standardized packs had higher levels of noticing warnings than never users of standardized packs ( $\mathrm{OR}=2.86,95 \% \mathrm{CI}: 2.19-3.74, \mathrm{p}<0.001)$. The association remained when adjusted for demographic (age, gender, 
Table 2 Direction of Effect and/or Key Findings: Response to Health Warnings

\begin{tabular}{|c|c|c|c|c|}
\hline Study & $\begin{array}{l}\text { Study Design and Data } \\
\text { Collection }\end{array}$ & Population & $\begin{array}{l}\text { Type of Comparison/ } \\
\text { Issues Explored }\end{array}$ & $\begin{array}{l}\text { Direction of Effect (Measures } \\
\text { Used) and/or Key Findings }\end{array}$ \\
\hline $\begin{array}{l}\text { Aleyan } \\
\text { et } \mathrm{al}^{22}\end{array}$ & $\begin{array}{l}\text { Longitudinal online survey } \\
\text { Wave I: Jul-Sep } 2016 \\
\text { (early in transition period) } \\
\text { Wave 2: Feb-Jul } 2018 \\
\text { (nine-14 months after end } \\
\text { of transition period) }\end{array}$ & $\begin{array}{l}\text { Adult smokers I8+ } \\
\text { years } \\
\text { England, Germany, } \\
\text { Greece, Hungary, } \\
\text { Poland, Romania, } \\
\text { Spain } \\
\text { Wave I: } n=9547 \\
\text { Wave 2: } n=9724\end{array}$ & $\begin{array}{l}\text { Smokers in England (Tobacco } \\
\text { Products Directive new warnings } \\
\text { and UK standardized packs) vs } \\
\text { smokers in six other European } \\
\text { countries (Tobacco Products } \\
\text { Directive new warnings only) }\end{array}$ & $\begin{array}{l}\text { Favors UK standardized packs } \\
\text { (what participants report first } \\
\text { noticing on packs). } \\
\text { Warning salience increased } \\
\text { significantly at Wave } 2 \text { in England. } \\
\text { Increase in warning salience at } \\
\text { Wave } 2 \text { was greater in England than } \\
\text { in other six countries. }\end{array}$ \\
\hline $\begin{array}{l}\text { Drovandi } \\
\text { et } \mathrm{al}^{27}\end{array}$ & $\begin{array}{l}\text { Cross-sectional online } \\
\text { survey } \\
\text { Jun } 2018 \text { (approx. one year } \\
\text { after end of transition } \\
\text { period) }\end{array}$ & $\begin{array}{l}\text { Smokers } 19-74 \text { years } \\
\text { UK, Australia, Canada, } \\
\text { USA } \\
n=155 \text { UK } \\
n=532 \text { other countries }\end{array}$ & $\begin{array}{l}\text { Smokers in UK (UK standardized } \\
\text { packs) vs smokers in Australia, } \\
\text { Canada, USA (each countries' own } \\
\text { packs) }\end{array}$ & $\begin{array}{l}\text { Favors UK standardized packs } \\
\text { (perceived effectiveness of } \\
\text { warnings in prompting smokers to } \\
\text { quit). } \\
\text { Perceived effectiveness of warnings } \\
\text { higher in the UK; UK smokers less } \\
\text { negative about effect of warnings } \\
\text { on quitting. }\end{array}$ \\
\hline $\begin{array}{l}\text { MacGregor } \\
\text { et } \mathrm{al}^{24}\end{array}$ & $\begin{array}{l}\text { Focus groups } \\
\text { Feb-Mar 2017, towards } \\
\text { end of transition period }\end{array}$ & $\begin{array}{l}\text { Young people } 13-16 \\
\text { years } \\
\text { Mix of current } \\
\text { smokers, never } \\
\text { smokers, and tried } \\
\text { smoking } \\
\text { Scotland } \\
16 \text { groups, } n=82\end{array}$ & $\begin{array}{l}\text { Awareness of standardized packs, } \\
\text { perceptions as to their appeal, and } \\
\text { potential impact on smoking } \\
\text { attitudes and behavior }\end{array}$ & $\begin{array}{l}\text { Perceptions of warnings very } \\
\text { negative. }\end{array}$ \\
\hline $\begin{array}{l}\text { Mitchell } \\
\text { et al }\end{array}$ & $\begin{array}{l}\text { Focus groups } \\
\text { Nov } 2017 \text { ( } 6 \text { months after } \\
\text { end of transition period) } \\
\text { and Nov } 2018 \text { ( } 18 \text { months } \\
\text { after end of transition } \\
\text { period) }\end{array}$ & $\begin{array}{l}\text { Young people } 16-17 \\
\text { years } \\
\text { Mix of ever and never } \\
\text { smokers } \\
\text { Scotland } \\
8 \text { groups, } n=4 \mid\end{array}$ & $\begin{array}{l}\text { Awareness and perceptions of } \\
\text { standardized packs, reactions to } \\
\text { pack structures }\end{array}$ & $\begin{array}{l}\text { Warnings were perceived as clear, } \\
\text { noticeable, believable and off- } \\
\text { putting. }\end{array}$ \\
\hline $\begin{array}{l}\text { Moodie } \\
\text { et } \mathrm{a}^{26}\end{array}$ & $\begin{array}{l}\text { Cross-sectional online } \\
\text { survey } \\
\text { Feb-Apr 2017, towards } \\
\text { end of transition period }\end{array}$ & $\begin{array}{l}\text { Current smokers } \\
16-65+\text { years } \\
\text { England } \\
n=1865\end{array}$ & $\begin{array}{l}\text { Smokers who currently used } \\
\text { standardized packs vs smokers who } \\
\text { had never used standardized packs } \\
\text { (conducted Feb-Apr } 2017 \text { when } \\
\text { both standardized and fully branded } \\
\text { packs still on sale) }\end{array}$ & $\begin{array}{l}\text { Favors standardized packs } \\
\text { (noticing, reading or looking closely } \\
\text { at warning). } \\
\text { Current users more likely to notice } \\
\text { warnings and to read or look } \\
\text { closely at them. }\end{array}$ \\
\hline $\begin{array}{l}\text { Poundall } \\
\text { et } \mathrm{al}^{28}\end{array}$ & $\begin{array}{l}\text { Cross-sectional survey } \\
\text { Oct-Nov } 2016 \text { (early } \\
\text { transition period) }\end{array}$ & $\begin{array}{l}\text { University students } \\
\text { England } \\
\mathrm{n}=546\end{array}$ & $\begin{array}{l}\text { Fully branded packs vs standardized } \\
\text { packs (conducted Oct-Nov } 2016 \\
\text { when standardized packs not widely } \\
\text { available) }\end{array}$ & $\begin{array}{l}\text { Favors standardized packs (noticing } \\
\text { warnings, whether warnings would } \\
\text { put them off or make them want to } \\
\text { quit). }\end{array}$ \\
\hline $\begin{array}{l}\text { Retzler } \\
\text { et } \mathrm{al}^{29}\end{array}$ & $\begin{array}{l}\text { Eye-tracking experimental } \\
\text { study, within-subjects } \\
\text { design } \\
\text { Feb-May } 2017 \text { (late } \\
\text { transition period) }\end{array}$ & $\begin{array}{l}\text { Smokers } 19-58 \text { years } \\
\text { England } \\
n=47\end{array}$ & $\begin{array}{l}\text { Fully branded packs vs standardized } \\
\text { packs }\end{array}$ & $\begin{array}{l}\text { Favors standardized packs (eye } \\
\text { fixations on warnings). } \\
\text { Participants attended more to } \\
\text { warnings on standardized packs, in } \\
\text { terms of looking at warnings first } \\
\text { and for longer duration. }\end{array}$ \\
\hline
\end{tabular}


social grade) and smoking characteristics (quit attempts in past 12 months, HSI, and currently trying to quit/reduce) (adjusted $\mathrm{OR}=2.76,95 \% \mathrm{CI}: 2.10-3.63, \mathrm{p}<0.001$ ). The same study reported that $26.8 \%$ of the respondents said they had often or very often read or looked closely at the warnings on packs, with current users of standardized packs more likely than never users to have read or looked closely at the warnings on packs $(\mathrm{OR}=2.43,95 \% \mathrm{CI}: 1.70$ $3.46, \mathrm{p}<0.001)$. The association remained when adjusted for demographic (age, gender, social grade) and smoking characteristics (quit attempts in past 12 months, HSI, and currently trying to quit/reduce) (adjusted $\mathrm{OR}=2.16,95 \%$ CI: $1.51-3.10, \mathrm{p}<0.001)$.

Evidence from the quantitative studies raising more major methodological concerns was in a similar direction. Drovandi et $\mathrm{al}^{27}$ found that UK smokers were more likely than smokers in Australia, Canada and the USA to perceive that warnings were effective in prompting them to quit, but there were concerns about the sample, unclear reporting and interpretation. Poundall et $\mathrm{al}^{28}$ found that smokers and non-smokers were more likely to report noticing warnings on standardized packs than on fully branded packs and that smokers were more likely to report that warnings on standardized packs made them want to quit compared with fully branded pack warnings. The latter study, ${ }^{28}$ however, raised some major methodological concerns related to its sampling method, response rate and the inferences made from its results.

The two qualitative studies found that young people noticed warnings on standardized packs and felt that they were off-putting. In the Mitchell et $\mathrm{al}^{25}$ focus group study with 16- to 17-year-olds, warnings were considered clear, noticeable and believable, and thought to reduce the appeal of smoking and put them off smoking. In MacGregor et al's ${ }^{24}$ focus group study with 13 - to 16 year-olds, warnings were described very negatively, with some evoking visceral reactions. Never or occasional smokers were thought to be more susceptible to the warnings than regular smokers.

\section{Behavioral Responses}

Eight studies, six quantitative studies ${ }^{23,26,28,30,31}$ and two qualitative studies, ${ }^{24,25}$ examined behavioral outcomes relating to standardized packaging in the UK. Participants were asked for anticipated smoking behavior changes in some studies and for self-reported actual behavioral outcomes in others. None of the studies reported on smoking uptake, cessation or relapse prevention. One study raised some major methodological concerns, ${ }^{28}$ five studies raised minor methodological concerns, ${ }^{23-26,31}$ and two were appraised as raising no concerns. ${ }^{30}$ Table 3 summarizes the direction of effect and/or key findings for the results of the studies.

\section{Anticipated Behaviors}

Two related studies with teenagers in Scotland, both conducted 6 to 18 months after the transition period ended, examined the effects of differently shaped standardized packs on views of smoking behavior. ${ }^{23,25}$ Using crosssectional data, Mitchell et al's ${ }^{23}$ study with 12- to 17 -yearold never smokers found that images of all four standardized cigarette packs with different pack structures (regular, beveled-edge, slim, shoulder box) were considered off-putting, with the vast majority (87\%) indicating that they would select none of the packs if offered. Sub-group analysis, controlling for demographics and family and peer smoking, found that those who were susceptible to smoking, however, were significantly more likely to think that the packs would not put them off smoking and to select one of the packs if offered, than those who were not susceptible $\left(25 \%\right.$ vs $\left.7 \%, \chi^{2}(1)=29.70, p<0.001\right)$. For all four pack structures, not finding them off-putting was associated with susceptibility to smoking ( $A O R=2.73-3.69)$, although this sub-group was relatively small. When given standardized packs of five different shapes to handle and examine in Mitchell et al's ${ }^{25}$ focus groups study with 16- to 17-yearold never smokers and ever smokers, participants considered the slimmer pack and shoulder box, and to a lesser extent the beveled-edged and rounded-edged packs, less of a deterrent on smoking behaviors than the regular standardized pack shape.

Two cross-sectional studies during the transition period examined smokers' thoughts and intentions relating to quitting or cutting down. ${ }^{26,28}$ Moodie et $\mathrm{al}^{26}$ surveyed smokers in England aged 16 and older towards the end of the transition period and found that the look of the pack they were currently using made $25 \%$ of them more likely to think "somewhat" or "a lot" about quitting smoking. A subgroup analysis by standardized packaging use found that previous users $(\mathrm{OR}=2.05$, 95\% CI: 1.26-3.33 p=0.004; adjusted $\mathrm{OR}=1.90,95 \% \mathrm{CI}: 1.30-2.77, \mathrm{p}<0.001)$ and current users $(\mathrm{OR}=2.22,95 \% \mathrm{CI}: 1.55-3.20, \mathrm{p}<0.001)$ were more likely to indicate that they had thought about quitting than never users of standardized packs. A survey in the middle of the transition period of university students in England, ${ }^{28}$ gauging their own likely response to the 
Table 3 Direction of Effect and/or Key Findings: Behaviors

\begin{tabular}{|c|c|c|c|c|}
\hline Study & $\begin{array}{l}\text { Study Design and Data } \\
\text { Collection }\end{array}$ & Population & $\begin{array}{l}\text { Type of Comparison/ } \\
\text { Issues Explored }\end{array}$ & $\begin{array}{l}\text { Direction of Effect (Measures } \\
\text { Used) and/or Key Findings }\end{array}$ \\
\hline $\begin{array}{l}\text { MacGregor } \\
\text { et } \mathrm{al}^{24}\end{array}$ & $\begin{array}{l}\text { Focus groups } \\
\text { Feb-Mar } 2017 \text {, towards } \\
\text { end of transition period }\end{array}$ & $\begin{array}{l}\text { Young people } 13-16 \text { years } \\
\text { Mix of current smokers, } \\
\text { never smokers, and tried } \\
\text { smoking } \\
\text { Scotland } \\
16 \text { groups, } n=82\end{array}$ & $\begin{array}{l}\text { The probable impact of } \\
\text { standardized packs on smoking } \\
\text { behavior among young people }\end{array}$ & $\begin{array}{l}\text { Anticipated behaviors: } \\
\text { Packs would affect never or } \\
\text { occasional smokers, but } \\
\text { established smokers would } \\
\text { continue to smoke. }\end{array}$ \\
\hline $\begin{array}{l}\text { Mitchell } \\
\text { et } \mathrm{al}^{25}\end{array}$ & $\begin{array}{l}\text { Focus groups } \\
\text { Between Nov } 2017 \text { ( } 6 \\
\text { months after end of } \\
\text { transition period) and } \\
\text { Nov } 2018 \text { (18 months } \\
\text { after end of transition } \\
\text { period) }\end{array}$ & $\begin{array}{l}\text { Young people } 16-17 \text { years } \\
\text { Mix of ever and never } \\
\text { smokers } \\
\text { Scotland } \\
8 \text { groups, } n=4 \mid\end{array}$ & $\begin{array}{l}\text { Reactions to different } \\
\text { standardized cigarette pack } \\
\text { structures and perceived impact } \\
\text { on smoking behavior }\end{array}$ & $\begin{array}{l}\text { Anticipated behaviors: } \\
\text { Packs would put off people } \\
\text { considering starting but not } \\
\text { addicted smokers. Standardized } \\
\text { slim pack and shoulder box } \\
\text { would be less of a deterrent than } \\
\text { regular packs. }\end{array}$ \\
\hline $\begin{array}{l}\text { Mitchell } \\
\text { et al }{ }^{23}\end{array}$ & $\begin{array}{l}\text { Cross-sectional survey in } \\
\text { schools } \\
\text { Between Nov } 2017 \text { (6 } \\
\text { months after end of } \\
\text { transition period) and } \\
\text { Nov } 2018 \text { (18 months } \\
\text { after end of transition } \\
\text { period) }\end{array}$ & $\begin{array}{l}\text { Young people } 12-17 \text { years } \\
\text { Never smokers } \\
\text { Scotland } \\
n=507\end{array}$ & $\begin{array}{l}\text { Reactions to standardized } \\
\text { cigarette packaging; whether } \\
\text { permitted variations in pack } \\
\text { structure (eg, slim packs or } \\
\text { beveled-edged packs) influenced } \\
\text { reactions }\end{array}$ & $\begin{array}{l}\text { Anticipated behaviors: } \\
\text { Favors standardized packs (all } \\
\text { packs would put them off } \\
\text { smoking. Most would not select } \\
\text { a pack when asked to pick one.) } \\
\text { Elaborate pack structures were } \\
\text { preferred over regular pack } \\
\text { structures. }\end{array}$ \\
\hline $\begin{array}{l}\text { Poundall } \\
\text { et } \mathrm{al}^{28}\end{array}$ & $\begin{array}{l}\text { Cross-sectional survey } \\
\text { Oct-Nov } 2016 \text { (early } \\
\text { transition period) }\end{array}$ & $\begin{array}{l}\text { University students } \\
\text { England } \\
\mathrm{n}=546\end{array}$ & $\begin{array}{l}\text { Would smokers make behavior } \\
\text { changes such as quitting or } \\
\text { switching to a cheaper brand or } \\
\text { alternative products as a result of } \\
\text { the legislation }\end{array}$ & $\begin{array}{l}\text { Anticipated behaviors: } \\
\text { Some smokers reported they } \\
\text { were likely to switch products (to } \\
\text { RYO, cheaper brands or } \\
\text { e-cigarettes) in response to the } \\
\text { legislation. }\end{array}$ \\
\hline $\begin{array}{l}\text { Breton } \\
\text { et } \mathrm{al}^{30}\end{array}$ & $\begin{array}{l}\text { Longitudinal panel survey } \\
\text { Mar 20II-Dec } 2017 \text { (pre- } \\
\text { legislation to } 7 \text { months } \\
\text { after end of transition } \\
\text { period) }\end{array}$ & $\begin{array}{l}\text { Households who had } \\
\text { purchased tobacco, } \\
\text { e-cigarettes and Nicotine } \\
\text { Replacement Therapy } \\
\text { England, Scotland \& Wales } \\
n=||, 695 \\
\text { (average } n=|74| \text {, range } \\
\text { |332 to } 2186 \text { ) }\end{array}$ & $\begin{array}{l}\text { Comparing trends in household } \\
\text { tobacco and non-tobacco } \\
\text { nicotine product purchases } \\
\text { before, during and after the } \\
\text { introduction of plain packaging } \\
\text { for consumers' switching } \\
\text { behaviors }\end{array}$ & $\begin{array}{l}\text { Behaviors: } \\
\text { Tobacco or non-tobacco nicotine } \\
\text { products purchasing households } \\
\text { more likely to leave the panel } \\
\text { post-standardized packaging. }\end{array}$ \\
\hline $\begin{array}{l}\text { Breton } \\
\text { et } \mathrm{al}^{30}\end{array}$ & $\begin{array}{l}\text { Cross-sectional survey } \\
\text { Mar-May } 2018(10-12 \\
\text { months after end of } \\
\text { transition period) }\end{array}$ & $\begin{array}{l}\text { Smokers who had } \\
\text { changed tobacco product } \\
\text { past month } \\
\text { England, Scotland \& Wales } \\
\mathrm{n}=|06|\end{array}$ & $\begin{array}{l}\text { Consumer's choices after changes } \\
\text { in product availability associated } \\
\text { with implementation of } \\
\text { standardized packaging }\end{array}$ & $\begin{array}{l}\text { Behaviors: } \\
\text { Among recent tobacco } \\
\text { purchasers, most reported } \\
\text { buying the same brand. }\end{array}$ \\
\hline $\begin{array}{l}\text { Bogdanovica } \\
\text { et } \mathrm{al}^{31}\end{array}$ & $\begin{array}{l}\text { Cross-sectional survey } \\
\text { Mar } 2017 \text { (towards end of } \\
\text { transition period) }\end{array}$ & $\begin{array}{l}\text { Current smokers } 18-55+ \\
\text { years } \\
\text { England, Scotland \& Wales } \\
n=2033\end{array}$ & $\begin{array}{l}\text { If smokers had changed the } \\
\text { product they usually smoked in } \\
\text { the last } 6 \text { months }\end{array}$ & $\begin{array}{l}\text { Behaviors: } \\
\text { Some smokers reported they had } \\
\text { switched products (to cheaper } \\
\text { brands, larger packs or } \\
\text { e-cigarettes) in the last } 6 \text { months. }\end{array}$ \\
\hline
\end{tabular}

(Continued) 
Table 3 (Continued).

\begin{tabular}{|l|l|l|l|l|}
\hline Study & $\begin{array}{l}\text { Study Design and Data } \\
\text { Collection }\end{array}$ & Population & $\begin{array}{l}\text { Type of Comparison/ } \\
\text { Issues Explored }\end{array}$ & $\begin{array}{l}\text { Direction of Effect (Measures } \\
\text { Used) and/or Key Findings }\end{array}$ \\
\hline $\begin{array}{l}\text { Moodie } \\
\text { et al }{ }^{26}\end{array}$ & $\begin{array}{l}\text { Cross-sectional online } \\
\text { survey } \\
\text { Feb-Apr 2017 (towards } \\
\text { end of transition period) }\end{array}$ & $\begin{array}{l}\text { Current smokers 16-65+ } \\
\text { years } \\
\text { England } \\
\mathrm{n}=1865\end{array}$ & $\begin{array}{l}\text { Whether smokers had visited } \\
\text { a stop-smoking website in the } \\
\text { past month by use of } \\
\text { standardized packs (a stop- } \\
\text { smoking website is mandatory on } \\
\text { standardized packs) }\end{array}$ & $\begin{array}{l}\text { Behaviors: } \\
\text { Favors standardized packs (more } \\
\text { current and previous users of } \\
\text { standardized packs had visited } \\
\text { a stop-smoking website than non- } \\
\text { users of standardized packs). }\end{array}$ \\
\hline
\end{tabular}

legislation found that among the smokers, $46.2 \%$ would be likely to quit and three-fifths $(60.8 \%)$ would be likely to cut down on smoking. The survey also examined switching behaviors, with two-fifths $(41.5 \%)$ of smokers reporting that they would be likely to switch to rolling tobacco, under a third $(28.7 \%)$ to a cheaper brand and around a fifth $(19.3 \%)$ to e-cigarettes. ${ }^{28}$ However, the study raised major methodological concerns in relation to the sampling method, response rate and inferences drawn from the results.

The qualitative studies probed young people's views about the likely behavioral impact of standardized packs. MacGregor et al's ${ }^{24}$ focus group study with 13- to 16-yearolds towards the end of the transition period found divergent views. The most commonly expressed view was that established smokers, including some study participants, would continue to smoke as the health effects of smoking were widely known, changing the pack would not discourage addicted smokers and packs could be hidden. Never or occasional smokers were thought to be more susceptible to the standardized packs' negative image and therefore less likely to want to try smoking or become an established smoker. Several participants suggested the behavioral impact may be slight, as packs were only visible postpurchase due to point-of-sale display legislation. The Mitchell et $\mathrm{al}^{25}$ focus group study with 16- to 17 -yearolds, conducted 6 to 18 months after the transition period, found similar views on the likely behavioral impact. Several participants suggested that the packs would be offputting for people thinking about taking up smoking, in particular young people, but not for established, addicted smokers. Some males said they would engage in avoidant behaviors by concealing packs.

\section{Actual Behaviors}

Moodie et $\mathrm{al}^{26}$ surveyed smokers in England aged 16 and older towards the end of the transition period and found that $3.9 \%$ of the smokers overall reported having visited a stop-smoking website in the last month to get advice about quitting. Examining sub-groups by standardized packaging use, current users (4.6\%), previous users $(2.3 \%)$ and never users $(1.0 \%)$ had visited a stopsmoking website in the previous month; only frequencies were reported.

In Bogdanovica et al's ${ }^{31}$ cross-sectional survey of adults, conducted in the late transition period in England, Scotland and Wales, $31.4 \%$ of the smokers (95\% CI: 26 .$2-37.1 \%$ ) reported that they had switched to a different product in the previous 6 months. Of those who said they had switched, 55.9\% (95\% CI: 45.1-66.1\%) had changed to a cheaper brand, followed by switching to larger packs or e-cigarettes (small numbers, data not reported).

In Breton et al's ${ }^{30}$ longitudinal panel survey, household purchases of packs of 20 cigarettes increased from $17 \%$ in May 2016 to $93 \%$ in May 2017 (when 20 packs became the minimum pack size), with purchases of roll-your-own (RYO) tobacco in packs of at least 30 grams increasing from $70 \%$ in May 2016 to $99 \%$ in May 2017 (when 30 gram packs became the minimum pack size). Household purchases of cigarettes in the cheapest quartiles (Q1 and Q2) increased throughout the study while those in the most expensive quartiles (Q3 and Q4) decreased. Differences in average real price paid for cigarettes in each price quartile remained relatively constant until May 2017, when the cheapest prices (Q1 and Q2) converged and Q4 prices significantly increased. Household purchases of RYO in the cheapest quartile (Q1) decreased until February 2017 and then increased. Purchases in the second cheapest (Q2) and second most expensive quartiles (Q3) increased throughout the study. Differences in average real price paid per gram between the cheapest (Q1 and Q2) and most expensive (Q3 and Q4) quartiles increased over time.

From March 2011 to December 2017, the number of households purchasing only cigarettes fell from 875 to 
459 , as the number of households purchasing only RYO increased from 396 to 512 . The number of households purchasing e-cigarettes went from zero in March 2013 to 149 in December 2017. Among households starting as cigarette-only, or RYO-only purchasers, most remained with this initial product. For households starting as cigarette-only purchasers, the odds of switching to a nontobacco nicotine product increased significantly ( $\mathrm{p}=0.005$ ) during the first six months of the transition period (OR=1.74, 95\% CI: 1.18-2.57) but not thereafter. The likelihood of switching out of the dataset increased during the last six months of the transition period $(\mathrm{OR}=1.30,95 \% \mathrm{CI}: 0.08-1.58, \mathrm{p}=0.007)$ and doubled after May 2017 (OR=2.44, 95\% CI: 2.05-2.89, $\mathrm{p}<0.001)$. For households starting as RYO-only purchasers, switching to other tobacco products became significantly $(\mathrm{p}=0.044)$ less likely after the end of the transition period (OR=0.64, 95\% CI: 0.41-0.99). The likelihood of switching out of the dataset almost doubled after the end of the transition period ( $\mathrm{OR}=1.96,95 \% \mathrm{CI}: 1.64-2.36, \mathrm{p}<0.001)$. Overall, there was a marked increase in the number of households purchasing tobacco or non-tobacco nicotine products each month leaving the panel in the final months of the study.

In a related cross-sectional survey, ${ }^{30}$ conducted $10-12$ months after the transition period, the participants who had recently purchased tobacco (350 of 1061) were asked what they would do if the product they usually bought was unavailable. Most $(n=191)$ reported that they continued to use the same product, with 46 reporting switching to an alternative tobacco brand and 29 switching to a variant of the same brand.

\section{Discussion}

Eleven studies explored consumer response to standardized packaging in the UK. All were rated as having minor methodological concerns, except two which were rated as having major concerns. ${ }^{27,28}$ The findings consistently showed that standardized packaging increased warning salience and reduced the appeal of the packaging and smoking. There were mixed findings on harm perceptions. Studies reporting on anticipated or actual behavioral changes suggest that standardized packs may help deter youth from starting or continuing to smoke and increase cessationrelated behaviors among smokers, although no study directly explored uptake, cessation or prevention relapse.

The findings on warning salience and appeal are consistent with earlier reviews ${ }^{7,8}$ and research in Australia and
France. For instance, in Australia, cross-sectional and longitudinal surveys with smokers have typically found an increase in warning salience post-implementation, ${ }^{32-35}$ and where this was not the case research has found an increase in cognitive responses and forgoing cigarettes due to the warnings post-implementation. ${ }^{36}$ Longer-term research would be of value given that the studies in this synthesis review (and from Australia) explore response to warnings within two years of standardized packaging being implemented; the one study that has explored longer-term response to warnings, repeat cross-sectional school surveys in Australia, found that reading, attending to, and talking or thinking about warnings did not change between 2011 and 2017 (almost five years post-standardized packaging). ${ }^{37}$ In terms of appeal, research in Australia and France found that smokers were more likely to dislike standardized packs than fully branded packs, ${ }^{32,33,38}$ viewing them as less attractive, lower quality, less satisfying and embarrassing. ${ }^{33,38-40}$ School surveys in Australia similarly found a reduction in positive brand ratings, an increase in negative pack ratings and a decrease in positive pack ratings post-standardized packaging. ${ }^{41}$ As standardized packaging was introduced alongside new larger warnings in the UK (as in Australia and France), this needs to be taken into account when interpreting the findings. While it makes it more challenging to try to determine the role of each on warning salience and appeal, the Aleyan et $\mathrm{al}^{22}$ multi-country European survey suggests that simultaneously introducing revised warnings and removing full branding has a greater impact than just changing the warnings.

The studies included in this review showed mixed findings on harm perceptions, echoing research in Australia and France. For instance, repeat cross-sectional surveys with adolescent and adult smokers and nonsmokers in France found an increase in the perceived dangers of smoking and fear of the consequences of smoking post-standardized packaging, ${ }^{42,43}$ with smokers in Australia interviewed post-standardized packaging more likely than those interviewed pre-standardized packaging to believe that brands do not differ in harmfulness. ${ }^{33}$ Other findings from Australia however show no change among smokers in perceived exaggeration of harms, frequency of thoughts about harm, or the belief that brand variants do not differ in perceived harmfulness compared with a year before, ${ }^{33,39}$ with school surveys finding a decrease in the proportion of young people disagreeing that some cigarette brands contain more harmful substances than others post- 
standardized packaging. ${ }^{41}$ Further research is needed to attempt to understand this inconsistency.

With respect to behavioral response, studies in this review suggest that standardized packaging may help to deter youth from smoking or continuing to smoke, due to the warnings, pack appearance, and negative image created by the packs. The findings, limited to qualitative research and a cross-sectional school survey, are similar to those in a Cochrane review, where standardized packs were generally less likely to motivate smoking initiation than fully branded packs, ${ }^{12}$ and research in France and Australia. Repeat cross-sectional surveys found that following the introduction of standardized packaging, in France the proportion of non-smokers who had tried smoking decreased ${ }^{43}$ and in Australia never smokers were less likely to indicate that they would try smoking, and experimenters and ex-smokers less likely to indicate that they would smoke again. ${ }^{40}$

For smokers in the UK, standardized packaging was associated with increased thoughts of quitting during the transition period. Research in Australia has found standardized packaging to be associated with greater cessation-related behaviors. Smokers using standardized packs during the transition period were more likely than those using fully branded packs to have thought about quitting at least once a day in the past week and rate quitting as a higher priority. ${ }^{39} \mathrm{~A}$ cross-sectional tracking survey, where smokers were interviewed and followed up approximately one month later, found that compared to smokers who completed their follow-up survey prior to standardized packaging, those followedup in the early transition period showed significantly greater increases in rates of stopping themselves from smoking and higher quit attempt rates, those followedup in the late transition period showed greater increases in intentions to quit, and those followed-up poststandardized packaging showed more premature stubbing out of cigarettes and higher quit attempt rates. ${ }^{44}$ Additional analysis found that several baseline measures suggesting improved warning effectiveness and reduced appeal, increased the likelihood of quitting-related outcomes, ${ }^{45}$ for example, smokers attributing much more motivation to quit to warnings at baseline were more likely to have attempted to quit at follow-up. ${ }^{45}$ Other research found an increase in calls to a quitline shortly after the introduction of standardized packaging. ${ }^{46}$

\section{Strengths and Limitations}

In terms of strengths, a systematic approach was used in the two reviews that we synthesized, with extensive searches carried out to identify relevant studies. The studies that were included were checked for methodological rigor. As the authors were authors on four included studies, as can arise in systematic reviews conducted in specialized research areas, to minimize the risk of researcher bias study quality was assessed externally, by the EPPI-Centre.

The review also has a number of limitations. We intentionally restricted inclusion to peer-reviewed publications, but excluding the grey literature may have introduced a publication bias. As the data extraction process was conducted by a single reviewer, this could have introduced errors. There are also limitations with the studies included. Two were appraised as raising major concerns about the soundness of the data (eg, the sample and data collection were not described adequately) and analyses (eg, the appropriateness and reporting of the analyses). ${ }^{27,28}$ The qualitative studies lack representativeness and generalizability. The studies relied on self-report, with convenience sampling used in most studies. One study was conducted during the early transition period, when few standardized packs were on sale, and three more studies during the late transition period, when the novelty of products may have influenced responses. None of the longitudinal surveys directly explored behavioral responses. For all included studies, the findings should be considered in light of the fact that standardized packs were introduced at the same time as novel larger pictorial warnings, and an increased minimum pack size for cigarettes and rolling tobacco.

\section{Future Research}

While we purposefully focused on research within the $\mathrm{UK}$, it is critical that standardized packaging is evaluated elsewhere, particularly as published research on warning salience, appeal, harm or behavior seems to be restricted to the three early adopters of this policy (Australia, France and the UK). Research in the middle-income countries in Asia and South America that have implemented this policy, and low- and middle-income countries that will implement this policy, is crucial. It is also important to consider the unintended consequences of plain packaging. ${ }^{11}$ No studies exploring illicit tobacco were included in the synthesis review, but recent research, using Euromonitor data, suggests that there was no 
increase in smokers being offered illicit cigarettes in the UK or France. ${ }^{47}$ Research assessing the actual use of illicit tobacco, as has been explored in Australia, ${ }^{48,49}$ is needed however. ${ }^{50}$ Standardized packaging is only required for cigarettes and rolling tobacco in the UK, whereas in other countries it covers all tobacco products. Research exploring perceptions of other tobacco products in markets with standardized packaging, irrespective of whether these products are included within standardized packaging regulations, would be of value. Most countries have only recently introduced standardized packaging, and as such research exploring the longer-term response is not yet possible, but such research is particularly important, with only one study, in Australia, having considered longer-term response. ${ }^{37}$

\section{Acknowledgments}

The authors wish to thank Dr Alison O'Mara-Eves and Dr Dylan Kneale from the EPPI-Centre, at the Institute of Education (University College London), for acting as independent external assessors to conduct critical appraisal of each of the studies included within the two source reviews. We also thank authors of the included studies for sharing additional information about their studies with us. Finally, thanks to our colleagues Dr Allison Ford and Dr Catherine Best at the Institute for Social Marketing and Health for their work on the wider project.

\section{Funding}

The work was undertaken by the authors as part of the National Institute for Health Research Public Health Policy Research Unit (PHPRU) (grant no. PHSEZQ4722-B) and the Public Health Research Consortium (grant no. PHPEHF50-30). The PHPRU is funded by the National Institute for Health Research and the Public Health Research Consortium was funded by the then Department of Health Policy Research Programme. The views expressed in the publication are those of the authors and not necessarily those of the NHS, the National Institute for Health Research, the Department of Health and Social Care or its arm's length bodies, and other Government Departments.

\section{Disclosure}

The authors report no conflicts of interest in this work.

\section{References}

1. World Health Organisation. Guidelines for implementation of Article 11 of the WHO Framework Convention on Tobacco Control; 2008. Available from: www.who.int/fctc/guidelines/article_11.pdf. Accessed March 25, 2021.

2. World Health Organisation. Guidelines for implementation of Article 13 of the WHO framework convention on tobacco control; 2008. Available from: www.who.int/fctc/guidelines/article_13.pdf?ua=1. Accessed March 25, 2021.

3. Australian Government. Tobacco Plain Packaging Act 2011. Australia: Commonwealth of Australia; 2011.

4. Department of Health. Consultation on standardised packaging of tobacco products; 2012. Available from: https://assets.publishing.ser vice.gov.uk/government/uploads/system/uploads/attachment_data/ file/170568/dh_133575.pdf. Accessed March 25, 2021.

5. Moodie C, Hastings G, Ford A. A Brief Review of Plain Packaging Research for Tobacco Products. Report Prepared for the Department of Health. Stirling: Centre for Tobacco Control Research, University of Stirling; 2009.

6. Quit Victoria, Cancer Council Victoria. Plain packaging of tobacco products: a review of the evidence; 2011. Available from: www.cancer vic.org.au/downloads/mini_sites/Plain-facts/TCUCCVEvOverview_ FINALAUG122011.pdf. Accessed March 25, 2021.

7. Moodie C, Stead M, Bauld L, et al. Plain Tobacco Packaging: A Systematic Review. Report Prepared for the Department of Health. Stirling: Centre for Tobacco Control Research, University of Stirling; 2012.

8. Moodie C, Angus K, Bauld L, et al. Plain Tobacco Packaging Research: An Update. Stirling, Scotland: Centre for Tobacco Control Research, University of Stirling; 2013.

9. Stead M, Moodie C, Angus K, et al. Is consumer response to plain/ standardised tobacco packaging consistent with framework convention on tobacco control guidelines? A systematic review of quantitative studies. PLoS One. 2013;8:e75919. doi:10.1371/journal. pone.0075919

10. Hammond D. Standardized Packaging of Tobacco Products: Evidence Review. Prepared on Behalf of the Irish Department of Health. 2014.

11. Smith CN, Kraemer JD, Johnson AC, et al. Plain packaging of cigarettes: do we have sufficient evidence? Risk Manage Healthcare Policy. 2015;8:21. doi:10.2147/RHMP.S63042

12. McNeill A, Gravely S, Hitchman SC, et al. Tobacco packaging design for reducing tobacco use. Cochr Database Syst Rev. 2017;4: CD011244. doi:10.1002/14651858.CD011244.pub2

13. Lilic N, Stretton M, Prakash M. How effective is the plain packaging of tobacco policy on rates of intention to quit smoking and changing attitudes to smoking? ANZ J Surgery. 2018;88(9):825-830. doi:10.11 11/ans. 14679

14. Drovandi A, Teague PA, Glass B, et al. A systematic review of the perceptions of adolescents on graphic health warnings and plain packaging of cigarettes. Syst Reviews. 2019;8(1):25. doi:10.1186/ s13643-018-0933-0

15. Moodie C, Angus K, Stead M. A Systematic Review of Research Exploring the Response of Consumers, Retailers and Tobacco Companies to Standardised Packaging in the United Kingdom. Stirling, Scotland: Centre for Tobacco Control Research, University of Stirling; 2019. https://dspace.stir.ac.uk/retrieve/327483ea-7f8b4a6c-82d2-0f6e24b125ec/Standardized\%20packaging\%20PHRC_ Final.pdf. Accessed March 25, 2021.

16. Moodie C, Angus K, Ford A, et al. A Systematic Review of Research (2019-2020) Exploring the Response of Consumers, Retailers and Tobacco Companies to Standardised Packaging in the United Kingdom. Stirling. Scotland: University of Stirling; unpublished 
17. HM Government. Standardised Packaging of Tobacco Products Regulations 2015; 2015. Available from: www.legislation.gov.uk/ uksi/2015/829/pdfs/uksi_20150829_en.pdf. Accessed March 25, 2021.

18. United Kingdom Government. Tobacco and Related Products Regulations 2016; 2016. Available from: www.legislation.gov.uk/uksi/ 2016/507/pdfs/uksi_20160507_en.pdf. Accessed March 25, 2021.

19. Moher D, Liberati A, Tetzlaff J, et al. Preferred reporting items for systematic reviews and meta-analyses: the PRISMA statement. PLoS Med. 2009;6(7):e1000097. doi:10.1371/journal.pmed.1000097

20. Evans-Reeves KA, Hiscock R, Lauber K, et al. Prospective longitudinal study of tobacco company adaptation to standardised packaging in the UK: identifying circumventions and closing loopholes. BMJ Open. 2019;9:e028506. doi:10.1136/bmjopen-2018-028506

21. Hiscock R, Augustin NH, Branston JR, et al. Longitudinal evaluation of the impact of standardised packaging and minimum excise tax on tobacco sales and industry revenue in the UK. Tob Control. in press. doi:10.1136/tobaccocontrol-2019-055387

22. Aleyan S, Driezen P, McNeill A, et al. Evaluating the impact of introducing standardised packaging with larger health-warning labels in England: findings from adult smokers within the EUREST-PLUS ITC Europe Surveys. Eur J Pub Health. 2020;30(Supplement_3): iii91-7. doi:10.1093/eurpub/ckaa053

23. Mitchell D, Critchlow N, Moodie C, et al. Reactions to standardized cigarette packs with varying structural designs, and the association with smoking susceptibility: a post-implementation cross-sectional survey with never-smoking adolescents in Scotland. Nicot Tob Res. 2020;22:2041-2050. doi:10.1093/ntr/ntaa109

24. MacGregor A, Delaney H, Amos A, et al. It's like sludge green': young people's perceptions of standardised tobacco packaging in the UK. Addiction. 2020;115:1736-1744. doi:10.1111/add.14999

25. Mitchell D, Moodie C, Critchlow N, et al. Adolescents' perceptions of standardised cigarette packaging: a focus group study in Scotland. BMC Pub Health. 2019;19:1227. doi:10.1186/s12889-019-7552-0

26. Moodie C, Brose LS, Hyun L, et al. How did smokers respond to standardised cigarette packaging with new, larger health warnings in the United Kingdom during the transition period? A cross-sectional online survey. Addict Res Theory. 2020;28:53-61. doi:10.1080/16066 359.2019.1579803

27. Drovandi A, Teague PA, Glass B, et al. Smoker perceptions of health warnings on cigarette packaging and cigarette sticks: a four-country study. Tob Ind Dis. 2019:17. doi:10.18332/tid/104753.

28. Poundall T, Bogdanovica I, Langley T. A cross-sectional study of the impact of standardised tobacco packaging legislation on university students. J Child Adolescent Subst Abuse. 2018;27:165-173. doi:10. 1080/1067828X.2018.1431992

29. Retzler C, Shiraj N, Retzler J. Eye movement data reveal increased attention to combined health warnings on cigarette packs. Drug Alc Depend. 2019;194:336-340. doi:10.1016/j.drugalcdep.2018.11.004

30. Breton MO, Britton J, Huang Y, et al. Cigarette brand diversity and price changes during the implementation of plain packaging in the United Kingdom. Addiction. 2019;113:1883-1894. doi:10.1111/add. 14282

31. Bogdanovica I, Breton MO, Langley T, et al. Awareness of standardised tobacco packaging among adults and young people during the final phase of policy implementation in Great Britain. Int J Environ Res Pub Health. 2017;14:858. doi:10.3390/ijerph14080858

32. Dunlop SM, Dobbins T, Young JM, et al. Impact of Australia's introduction of tobacco plain packs on adult smokers' pack-related perceptions and responses: results from a continuous tracking survey. BMJ Open. 2014;4:e005836. doi:10.1136/bmjopen-2014005836
33. Wakefield M, Coomber K, Zacher M, et al. Australian adult smokers' responses to plain packaging with larger graphic health warnings 1 year after implementation: results from a national cross-sectional tracking survey. Tob Control. 2015;24:ii17-25. doi:10.1136/tobaccocontrol-2014-052050

34. Nagelhout GE, Osman A, Yong HH, et al. Was the media campaign that supported Australia's new pictorial cigarette warning labels and plain packaging policy associated with more attention to and talking about warning labels? Addict Behav. 2015;49:64-67. doi:10.1016/j. addbeh.2015.05.015

35. Yong HH, Borland R, Hammond D, et al. Smokers' reactions to the new larger health warning labels on plain cigarette packs in Australia: findings from the ITC Australia project. Tob Control. 2016; 25:181-187. doi:10.1136/tobaccocontrol-2014-051979

36. Swayampakala K, Thrasher JF, Yong HH, et al. Over-time impacts of pictorial health warning labels and their differences across smoker subgroups: results from adult smokers in Canada and Australia. Nicot Tob Res. 2018;20(7):888-896. doi:10.1093/ntr/ntx134

37. White VM, Guerin N, Williams T, et al. Long-term impact of plain packaging of cigarettes with larger graphic health warnings: findings from cross-sectional surveys of Australian adolescents between 2011 and 2017. Tob Control. 2019;28:e77-e84. doi:10.1136/tobaccocontrol-2019-054988

38. Pasquereau A, Andler R, Guignard R, et al. Smokers' perception of cigarette packaging in France before and after the plain packaging. Eur J Pub Health. 2020;30:(Suppl.5):636-7. doi:10.1093/eurpub/ ckaa166.290

39. Wakefield MA, Hayes L, Durkin S, et al. Introduction effects of the Australian plain packaging policy on adult smokers: a cross-sectional study. BMJ Open. 2013;3(7):e003175. doi:10.1136/bmjopen-2013003175

40. Dunlop S, Perez D, Dessaix A, et al. Australia's plain tobacco packs: anticipated and actual responses among adolescents and young adults 2010-2013. Tob Control. 2017;26:617-626. doi:10.1136/tobaccocontrol-2016-053166

41. White V, Williams T, Wakefield M. Has the introduction of plain packaging with larger graphic health warnings changed adolescents' perceptions of cigarette packs and brands? Tob Control. 2015;24 (Supp12):ii42-9. doi:10.1136/tobaccocontrol-2014-052084

42. El-Khoury F, Bolze C, Gomajee R, et al. Lower smoking rates and increased perceived harm of cigarettes among French adults one year after comprehensive tobacco control measures. Drug Alc Dep. 2019;201:65-70. doi:10.1016/j.drugalcdep.2019.03.025

43. Lesueur FE, Bolze C, Gomajee R, et al. Plain tobacco packaging, increased graphic health warnings and adolescents' perceptions and initiation of smoking: dePICT, a French nationwide study. Tob Control. 2019;28(e1):e31-6. doi:10.1136/tobaccocontrol-2018-054573

44. Durkin S, Brennan E, Coomber K, et al. Short-term changes in quitting-related cognitions and behaviours after the implementation of plain packaging with larger health warnings: findings from a national cohort study with Australian adult smokers. Tob Control. 2015;24(Suppl 2):ii26-32. doi:10.1136/tobaccocontrol-2014-052058

45. Brennan E, Durkin S, Coomber K, et al. Are quitting-related cognitions and behaviours predicted by proximal responses to plain packaging with larger health warnings? Findings from a national cohort study with Australian adult smokers. Tob Control. 2015;24(Suppl 2): ii33-41. doi:10.1136/tobaccocontrol-2014-052057

46. Young JM, Stacey I, Dobbins TA, et al. Association between tobacco plain packaging and Quitline calls: a population-based, interrupted time-series analysis. Med J Australia. 2014;200:29-32. doi:10.5694/ mja13.11070 
47. Laverty AA, Millett C, Hopkinson NS, et al. Introduction of standardised packaging and availability of illicit cigarettes: a difference-indifference analysis of European Union survey data 2015-2018. Thorax. 2021;76(1):89-91. doi:10.1136/thoraxjnl-2020-215708

48. Scollo M, Zacher M, Coomber K, et al. Use of illicit tobacco following introduction of standardised packaging of tobacco products in Australia: results from a national cross-sectional survey. Tob Control. 2015;24:ii76-ii81. doi:10.1136/tobaccocontrol-2014-052072
49. Scollo M, Zacher M, Durkin S, et al. Early evidence about the predicted unintended consequences of standardised packaging of tobacco products in Australia: a cross-sectional study of the place of purchase, regular brands and use of illicit tobacco. BMJ Open. 2014;4:e005873. doi:10.1136/bmjopen-2014-005873

50. Moodie C. Looking beyond the smoke and mirrors. Thorax. 2021;76 (1):2. doi:10.1136/thoraxjnl-2020-216302

\section{Publish your work in this journal}

Risk Management and Healthcare Policy is an international, peerreviewed, open access journal focusing on all aspects of public health, policy, and preventative measures to promote good health and improve morbidity and mortality in the population. The journal welcomes submitted papers covering original research, basic science, clinical \& epidemiological studies, reviews and evaluations, guidelines, expert opinion and commentary, case reports and extended reports. The manuscript management system is completely online and includes a very quick and fair peer-review system, which is all easy to use. Visit http://www.dovepress.com/testimonials.php to read real quotes from published authors. 